\title{
STEREOLOGY, AN UNBIASED METHODOLOGICAL APPROACH TO STUDY PLANT ANATOMY AND CYTOLOGY: PAST, PRESENT AND FUTURE
}

\author{
LUCIE KUBÍNOVÁ ${ }^{\varpi, 1}$, BARBORA RADOCHOVÁ ${ }^{1,2}$, ZUZANA LHOTÁKOVÁ ${ }^{2}$ ZUZANA KuBÍNOVÁ \\ JANA ALBRECHTOVÁ ${ }^{2}$ \\ ${ }^{1}$ Department of Biomathematics, Institute of Physiology of the Czech Academy of Sciences, Vídeňská 1083, \\ Prague 4, CZ-14220, Czech Republic; ${ }^{2}$ Department of Experimental Plant Biology, Faculty of Science, Charles \\ University, Viničná 5, Prague 2, Czech Republic \\ e-mail: lucie.kubinova@fgu.cas.cz, barbora.radochova@fgu.cas.cz,zuza.lhotak@seznam.cz, \\ kubinova@natur.cuni.cz,jana.albrechtova@natur.cuni.cz \\ (Received October 11, 2017; revised November 22, 2017; accepted November 26, 2017)
}

\begin{abstract}
This review presents an historical overview of stereological methods used for the quantitative evaluation of plant anatomical and cytological structures. It includes the origins of these methods up to the most recent developments such as the application of stereology based on 3D images. We focus especially on leaf, as the vast majority of studies of plant microscopic structure examine this organ. An overview of plant cell ultrastructure measurements as well as plant anatomical characteristics (e.g., plant tissue volume density, internal leaf surface area, number and mean size of mesophyll cells and chloroplast number), which were estimated by stereological methods most frequently, is presented. We emphasize the importance of proper sampling needed for unbiased measurements. Furthermore, we mention other methods used for plant morphometric studies and briefly discuss their relevance, precision, unbiasedness and efficiency in comparison with unbiased stereology. Finally, we discuss reasons for the sparse use of stereology in plant anatomy and consider the future of stereology in plant research.
\end{abstract}

Keywords: chloroplast, confocal microscopy, leaf anatomy, mesophyll, stereological methods, systematic uniform random sampling

\section{INTRODUCTION}

Plant anatomical and cytological structure has been studied since the introduction of the first magnifying devices in the 16th century. By the end of the 19th century, a number of basic developmental and functional concepts in plant anatomy were well understood (Eames and MacDaniels, 1925). For example, Julius von Sachs (1834-1897) proposed the first physiological classification of plant tissues based on their origin from uniform meristem. While some quantitative methods for studying physiological processes in plant organisms were being established, these early findings were largely based on descriptive analyses of plant anatomical structure. There was a clear need for quantitative evaluation of plant anatomy for studying relations between the function and structure of the plant body. Thus, plant scientists began to quantitatively assess anatomical characteristics, initially by morphometric, intuitive methods, and later by more rigorous approaches made possible by stereological methods.
This review presents the history of stereology applied in plant studies and discusses other methods for measuring plant structural parameters. Particular focus is given to the evaluation of leaf structure as the leaf is the most frequently studied plant organ. This is due to the fact that the specific leaf tissues, cells, and organelles (Figs. 1, 2,8) are involved in the transfer of carbon dioxide during the process of light capture and photosynthesis, which has crucial importance for the function of the plant organism. Quantitative analysis of changes in the leaves can be very helpful in many applications studying the effect of environmental factors on plants, such as analysis of the effect of air pollution (Albrechtová et al., 2007), elevated $\mathrm{CO}_{2}$ concentration (Lhotáková et al., 2012) or temperature (Juurola et al., 2005). Moreover, leaf geometrical characteristics may be useful for interpreting physiological measurements, three-dimensional (3D) modelling during photosynthesis (Juurola et al., 2005) and for phenotyping (Flood et al., 2016). 

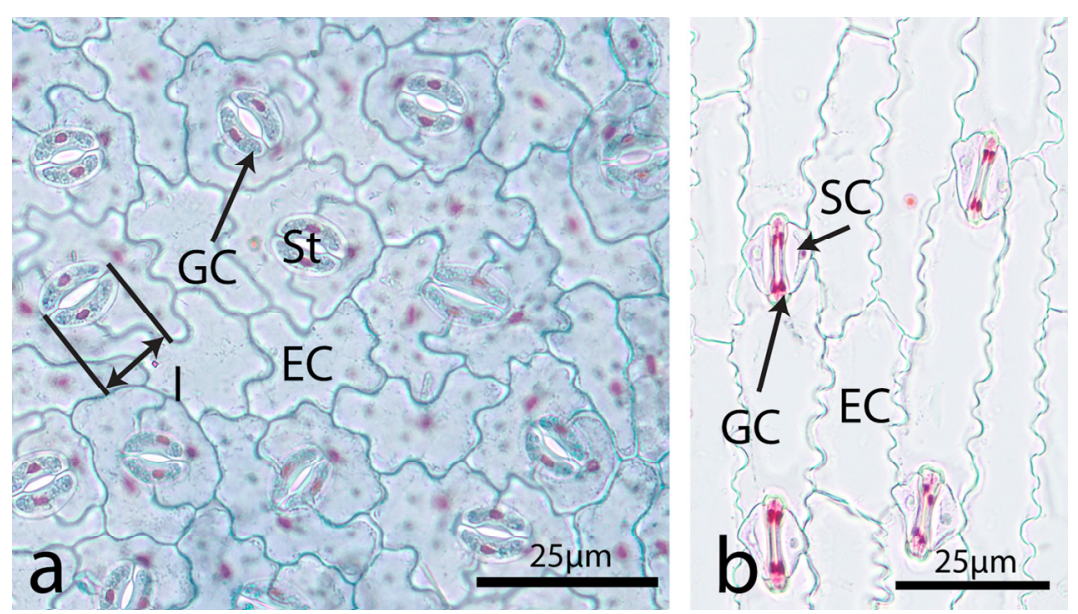

Fig. 1. Leaf epidermis. (a) Oregano (Origanum spp.) - dicotyledonous plant. St-stoma composed of two guard cells (GC), EC-epidermal cell, l-stoma length. (b) Maize (Zea mays L.) - monocotyledonous plant. Stomatal apparatus: two dumble-shaped guard cells (GC) and two subsidiary cells (SC), EC-epidermal cell.
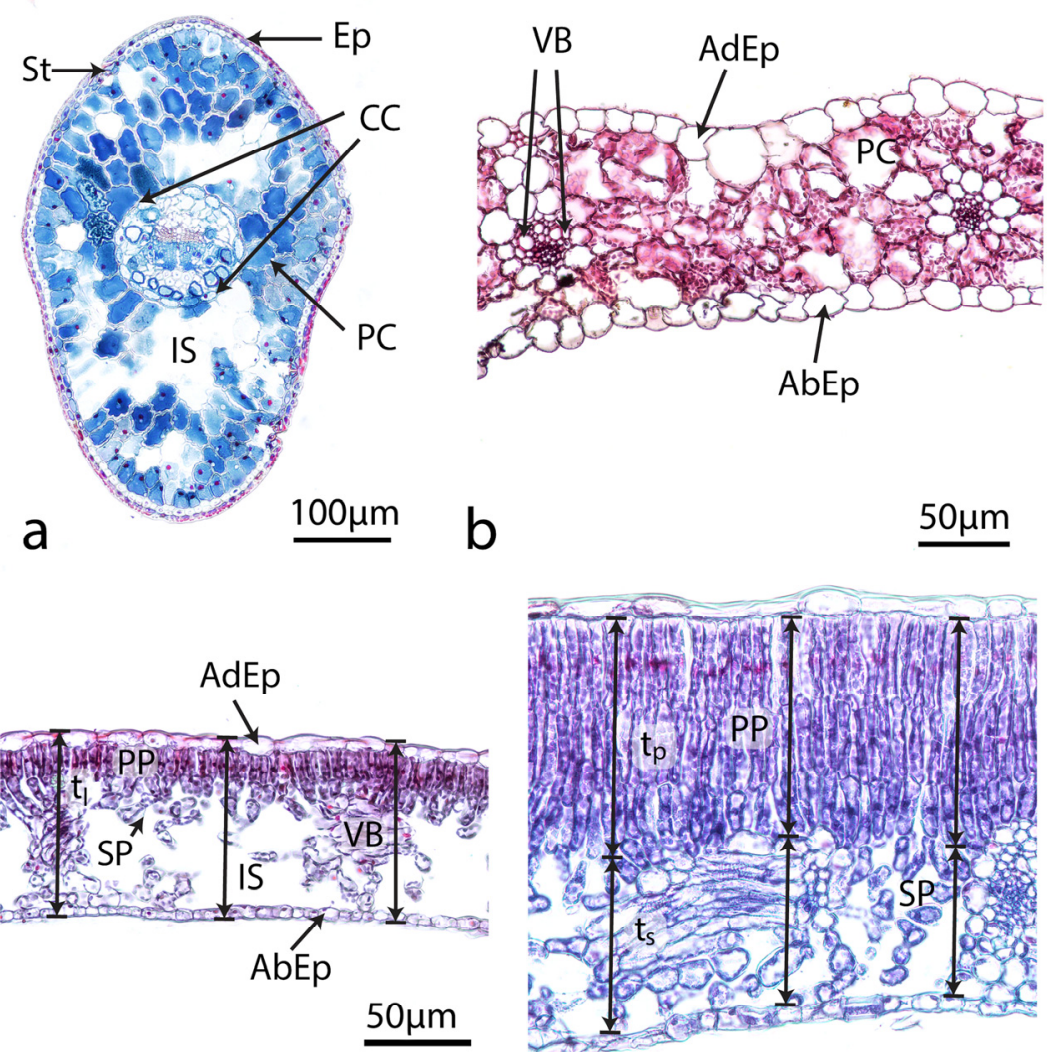

b

$50 \mu \mathrm{m}$

C

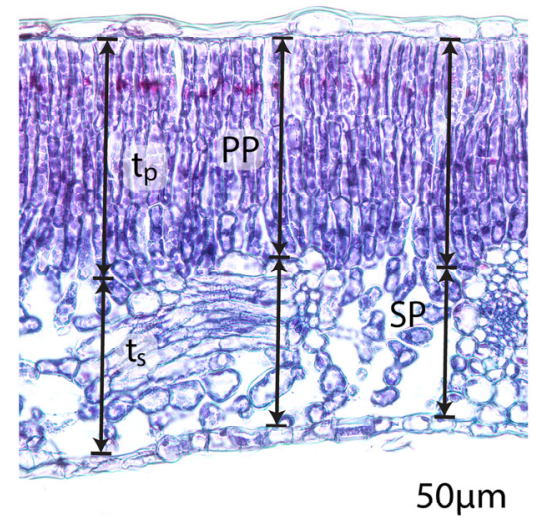

Fig. 2. Leaf internal structure in cross sections. (a) Norway spruce needle (Picea abies L. Karst): Ep epidermis, St - stoma, CC - central cylinder with vascular tissues (round structure between arrows), mesophyll composed of parenchyma cells (PC) and intercellular spaces (IS). (b) Monocotyledonous leaf (barley, Hordeum vulgare L.): AdEp - adaxial epidermis, AbEp - abaxial epidermis, VB - vascular bundle, PC mesophyll parenchyma cell. (c, d) Dorsiventral leaf (apple tree, Malus spp.): AdEp - adaxial epidermis, AbEp - abaxial epidermis, VB - vascular bundle, mesophyll composed of palisade parenchyma (PP), spongy parenchyma (SP), and intercellular spaces (IS). Shade leaf (c) with one layer of palisade parenchyma and sun leaf (d) with three layers of palisade parenchyma. $t_{l}$ - leaf thickness, $t_{p}$ - palisade parenchyma thickness, $t_{s}-$ spongy parenchyma thickness. 


\section{SHORT HISTORY OF QUANTIFICATION OF PLANT ANATOMICAL STRUCTURE}

The earliest quantitative data characterizing plant anatomy were published by Friedrich Wilhelm Heinrich Alexander von Humboldt already in 1786 who presented data on stomatal density (i.e., number of stomata per unit leaf area, see Fig. 1; Pazourek, 1988). Since then, many plant anatomists have used quantitative methods in their research, quite often in connection with physiological (particularly ecophysiological) and taxonomic studies, as summarized in reviews by Nátr (1988) and Pazourek (1988).

In the history of the development of quantitative approaches to investigating plant anatomy, the work of Salisbury (1928) is of particular note. Salisbury introduced the application of statistical methods in the analysis of quantitative data. He focused on determining stomatal distribution on the leaf surface and tried to prove the relations between various stomatal characteristics. He introduced the concept of stomatal index - the percentage of the number of stomata per unit leaf area with respect to the number of epidermal cells including stomata in the same unit area. A key finding of this study was determining stomatal index as less variable than stomatal density (i.e., number of stomata per unit leaf area) within a particular plant species.

In general, stomatal density and stoma length in the leaves were found to be the most frequently studied plant anatomical parameters. Stoma length is usually evaluated from epidermal peels or imprints, i.e. from practically two-dimensional (2D) structures (Fig. 1). Leaf thickness or thickness of its tissue layers is another frequently reported parameter. It is usually measured in 2D leaf cross-sections (Fig. 2c). The thickness of tissue layers was often measured in dorsiventral leaves (Turell, 1936; Wylie, 1949). This parameter can be useful when studying important physiological phenomena associated with irradianceaffected leaf morphogenesis, e.g., differentiation of dorsiventral leaves into thicker and denser sun leaves with more layers of palisade mesophyll parenchyma in comparison with shade leaf ecotypes (Fig. 2 c, d). In other plant organs, the most frequently measured parameter was the length of the root system. The root length in 2D was usually measured by the lineintercept method (Newmann, 1966), the principle of which had already been proposed by Buffon in 1777 .

In the studies of internal leaf structure (Fig. 2), the physiologically important characteristics most often measured were the number and dimensions of mesophyll cells, internal leaf surface area (i.e., the surface area of mesophyll cell walls adjoining the intercellular spaces), and the proportion of intercellular spaces. In one of the first comprehensive studies of leaf mesophyll, Meyer (1923) measured the dimensions of mesophyll palisade cells - the ratio of their length to the width, variations in the length of palisade cells within a blade, the number of palisade cell layers, the angle of orientation of palisade cells to the leaf surface, and the arm palisade cells surface area. The following methods for measurement of mesophyll parameters were most frequently used: Mesophyll cell dimensions were usually measured by applying a model-based approach, i.e., assuming that the cells could be modelled by simple geometrical bodies (Maksymowych, 1963; Chonan, 1966; 1970). The number of mesophyll cells was most frequently obtained by counting isolated cells after maceration (Maksymowych, 1959). Regarding internal leaf surface area, Turrell (1934) also applied a model-based approach. He emphasized the importance of this parameter for photosynthetic performance, since the gas exchange is via exposed mesophyll cell walls. Furthermore, Nius (1931) examined the physiological importance of the relative volume of intercellular spaces using the infiltration method according to Unger (1854).

Following the development of electron microscopy, the first quantitative measurements of chloroplast ultrastructure emerged in the 1960s. Parameters such as the number of grana per chloroplast or thylakoids per granum were measured and 3D models of chloroplasts were introduced (Wehrmeyer and Röbbelen, 1965; Paolillo and Falk, 1966). Stereological methods were increasingly applied in the following decades, including estimating area and/or volume densities of different chloroplast compartments (Gamalei and Kulikov, 1978; Fagerberg, 1983; Kutík et al., 1984).

After the establishment of stereology as a new scientific discipline in the 1960s and 70s (Weibel, 1979; Howard and Reed, 1998), design-based stereological methods emerged and began to be used also in quantitative studies of plant structures. The first applications of stereology in plant anatomy were published by Pazourek (1975; 1977), Chabot and Chabot (1977), Parkhurst (1982), Morris and Thain (1983), and Hajibagheri et al. (1984). Later, a number of design-based stereological methods for the estimation of various leaf characteristics were introduced by Kubínová (1987; 1989b; 1991; 1993; 1994). Characteristics highlighted included mesophyll volume, proportion of intercellular spaces in mesophyll, internal leaf surface area, mesophyll cell number and mean mesophyll cell volume, based on measurements in 2D leaf sections. Further- 
more, a specific approach to root length estimation using the stereological method of total vertical projections (Cruz-Orive and Howard, 1991) was presented by Albrechtová et al. (1998).

Although stereological methods proposed for the estimation of leaf characteristics from 2D sections were known to be reliable, they have rarely been applied. This is mainly due to their laborious nature. Therefore, there was a clear need for less demanding, efficient and unbiased methods for measuring physiologically important mesophyll anatomical characteristics, such as internal leaf surface area, mean mesophyll cell volume and cell number in the leaf. Stereological methods based on 3D images acquired by confocal microscopy, electron tomography and other modalities, are suitable for this purpose since they are efficient and unbiased. Moreover, confocal microscopy can be applied to thick fresh plant tissue sections, thus minimizing the time spent on tissue specimen preparation and avoiding deformation of tissues due to fixation and embedding procedures.

Stereology based on 3D confocal images, called confocal stereology (for reviews see Peterson, 1999; Kubínová et al., 2002; 2004, 2005; Kubínová and Janáček, 2015) is a contemporary approach that evaluates structures using a combination of stereological methods and confocal microscopy (Pawley, 1995; 2006) enabling the obtainment of perfectly registered stacks of thin serial optical sections (approx. $350 \mathrm{~nm}$ thick) within thick specimens. Digital images of such stacks represent 3D image data suitable for quantitative measurements. Howard et al. (1985) presented the first application of confocal microscopy to stereological measurements in their concept of an unbiased sampling brick. Confocal microscopy proved to be useful especially in the application of stereological methods based on spatial estimators evaluating small 3D samples of structures (Howard et al., 1985; Howard and Sandau, 1992; Kubínová and Janáček, 1998; Kubínová et al., 1999; Kubínová et al., 2002). A 3D sample of examined tissue can be analysed if a rectangle within the microscope's field of view is focused through. Using specialized software, different virtual test probes with an arbitrary pre-defined (e.g., random) position and orientation can be generated within the stack of sections and can be applied directly to this 3D image data. Albrechtová et al. (2007) presented the confocal stereological methods used to evaluate the mesophyll structure of narrow leaves, such as conifer needles. Kubínová et al. (2014) showed the application of confocal microscopy for counting chloroplasts in a mesophyll cell using optical disector principle (see below).

\section{OVERVIEW OF STEREOLOGICAL METHODS APPLIED IN PLANT ANATOMY}

Many of the stereological methods developed over the past fifty years can be applied (directly or after suitable modification) in studies of plant anatomical structures. In this review, we present the most frequently measured plant anatomical characteristics estimated by stereological methods.

Firstly, let us mention specific features of plant anatomical structures and relevant consequences: Plant organs and cells exhibit highly variable morphology with significant differences in dimension and shape. Anisotropy (arrangement with preferential orientation) is often observed in plant tissues as well as inhomogeneity, e.g., gradient in stomatal frequency in different parts of leaves, as shown by Slavík (1963) and Pazourek (1966; 1969). Gradients in tissue proportions within a leaf (Pazourek, 1977) and in mesophyll cell size along the leaf (Kubínová, 1989a) were also observed. Therefore, design-based stereological methods, yielding unbiased results without placing any assumptions on shape and arrangement of structures, are especially useful in quantitative plant anatomy.

The correct application of design-based stereological methods is critically dependent on proper sampling of tissue blocks, sections, test frames, point grids, etc. In stereology, geometrical properties of the object (in this case, the leaf) are derived from the information collected from relatively small parts of the object (i.e., leaf sections). Therefore, when evaluating a specific parameter of the object (e.g., the proportion of mesophyll in the leaf), just its specific parts (e.g., leaf sections) are measured to estimate the parameter. In order to obtain reasonable results, these parts should be sampled in a way ensuring the estimate is close enough to the true parameter value and yielding no systematic bias. This can be achieved by proper sampling, examples of which are presented below.

\section{SAMPLING}

\section{Systematic uniform random sampling (SURS)}

SURS ensures an efficient and convenient way of unbiased sampling. It has been used in the application of many stereological methods in plant research, such as the Cavalieri principle, point-counting, vertical sections, or disector methods. In leaf investigations, it can be applied for sampling leaf segments, 2D sections (Fig. 3, 4) and (3D) thick slices used in confocal stereology (Fig. 5). 


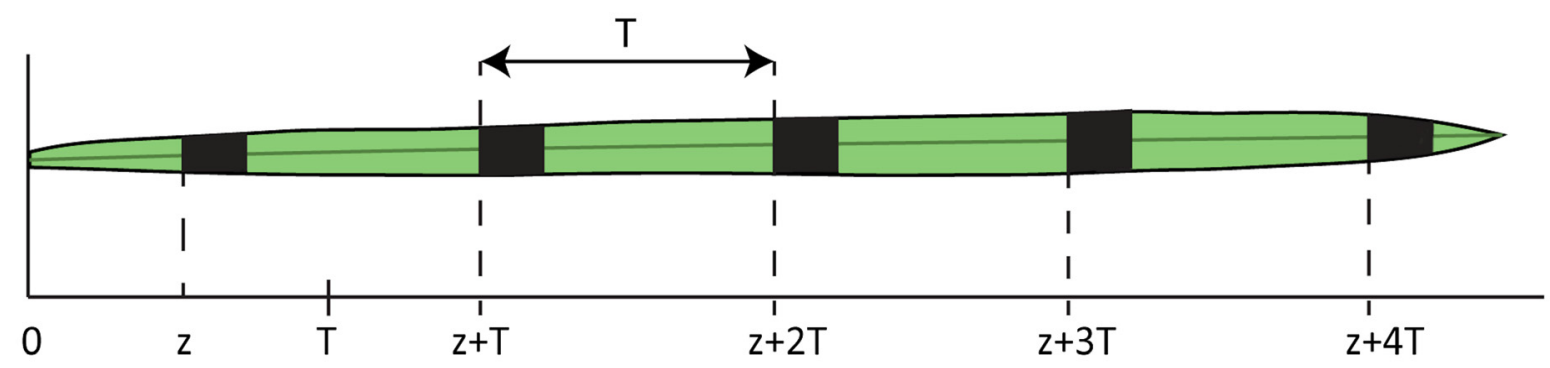

Fig. 3. Systematic uniform random sampling of segments and sections in a grass leaf. Firstly, the distance (T) $(\mathrm{mm})$ between two consecutive sections is chosen. For the position (z), a random number is then selected from the set $\{0,1, \ldots, T-1\}$. The transverse sections are made in the positions $z, z+T, z+2 T, \ldots$ For example, if $T=40$ $\mathrm{mm}, z=20 \mathrm{~mm}$, and the leaf length is $200 \mathrm{~mm}$, then the transverse sections would be cut at distances of $20 \mathrm{~mm}$, $60 \mathrm{~mm}, 100 \mathrm{~mm}, 140 \mathrm{~mm}$ and $180 \mathrm{~mm}$ from the leaf base. (After Kubinová, 1993.)

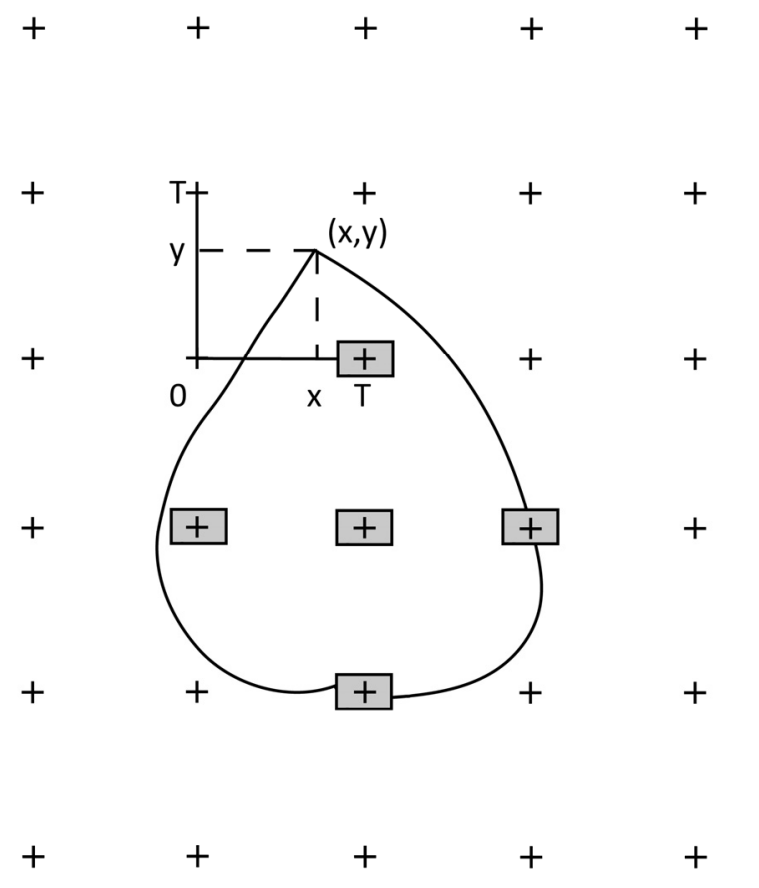

Fig. 4. Systematic uniform random sampling of segments and sections in a flat bifacial leaf. The distance $(T)(\mathrm{mm})$ between the central points of the leaf segments is chosen first. For the position $(x, y)$, two numbers are then (independently) selected at random from the set $\{0,1, \ldots, T-1\}$. By placing the leaf tip in the position $(x, y)$, the uniform random position of the grid of central points is ensured. The leaf segments are then cut as indicated in the figure and cross-sections are cut in the middle of the segments. (After Kubinová, 1993.)

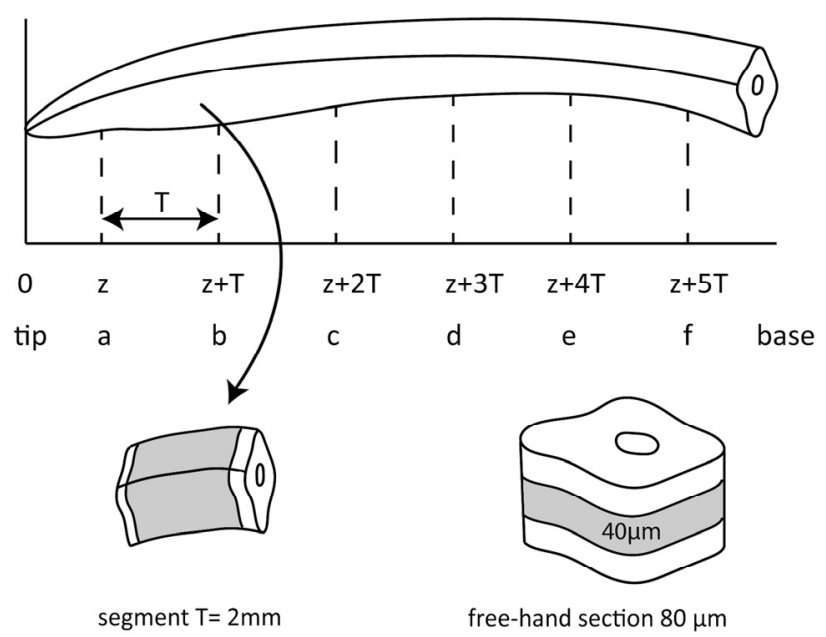

Fig. 5. Sampling design of needle specimen preparation. Upper: Systematic uniform random sampling of transverse free-hand sections: $z=$ random position of the first section within $(0 ; T]$. The distance T between free-hand sections is chosen first. In this specific case, $T=2 \mathrm{~mm}$. Positions of transverse sections along the needle longitudinal axis are denoted by $a$, $b, c, d, e, f$. Lower: Left: 2-mm-thick needle segment.

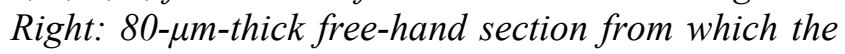
$40 \mu m$ thick stack of optical sections is acquired by confocal microscopy. (After Lhotáková et al., 2008.)

\section{Vertical uniform random sampling (VURS)}

VURS is applied in the vertical sections method (Baddeley et al., 1986). It enables the estimation of internal leaf surface area, which is one of the physiologically most important plant anatomical parameters. The practical application of VURS for narrow leaves is shown in Fig. 6. 


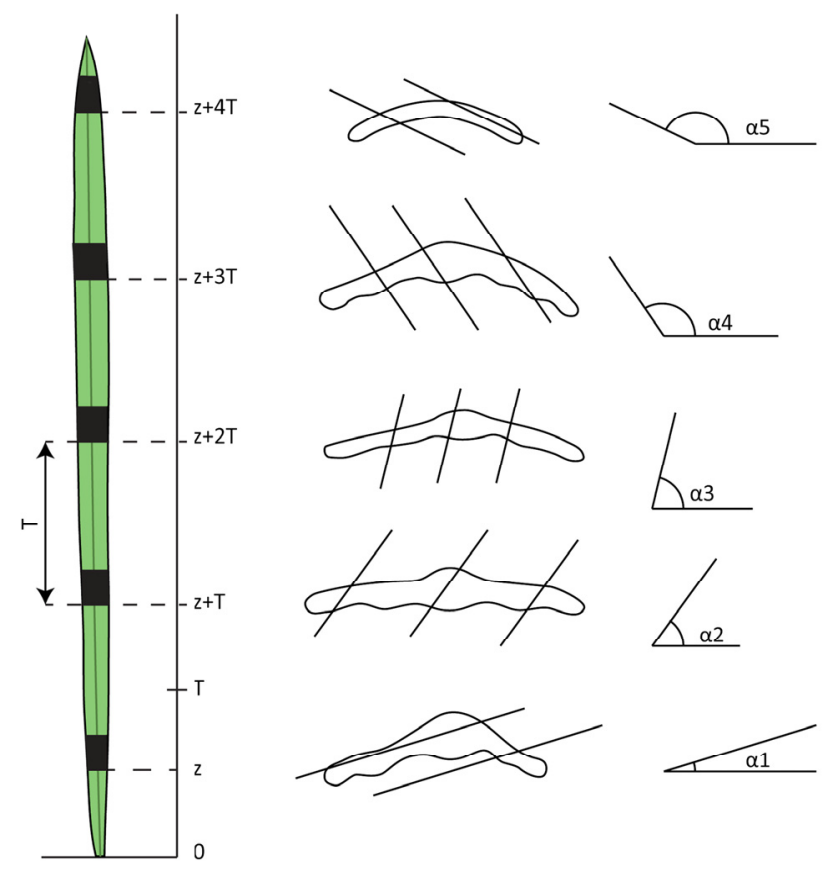

Fig. 6. Construction of vertical sections of the grass leaf. Firstly, the systematic uniform random sampling of leaf segments is done as shown on the left (see also Fig. 3). The direction of the vertical axis is chosen to be parallel to the main axis of the leaf, i.e. the vertical sections are cut in parallel with the leaf axis. At the same time they are cut around the leaf axis by an angle generated in the horizontal plane (which is perpendicular to the vertical plane) as illustrated in the figure: In the horizontal plane of the first segment (i.e. the nearest one to the leaf base; the face of the segment is shown as the lowest one in the figure), angle $\alpha_{1}\left(0^{\circ}<\alpha_{1}<180^{\circ}\right)$ is selected uniformly at random (e.g., $\alpha_{1}$ is a random number from the set $\left\{0^{\circ}\right.$, $\left.\left.10^{\circ}, 20^{\circ}, \ldots, 170^{\circ}\right\}\right)$. The vertical sections of the first segment are cut in this direction. With $m$ segments in the leaf, the direction of the vertical section in the $j$-th segment is given by the angle $\alpha_{j}=\alpha_{1}+(j-l) *\left(180^{\circ}\right)$ m) $(j=l, \ldots, m)$. (For example, if $m=5$ and $\alpha_{1}=10^{\circ}$, then $\alpha_{2}=10^{\circ}+1 *\left(180^{\circ} / 5\right)=46^{\circ}, \alpha_{3}=82^{\circ}, \alpha_{4}=$ $118^{\circ}$, and $\alpha_{5}=154^{\circ}$.) Within the segment, the series of equidistant parallel sections (illustrated by lines intersecting the faces of sampled segments seen from above) are cut in a way analogous to the one described in Fig. 3. (After Kubinová, 1993.)

\section{Unbiased sampling of particles by disector principle}

The unbiased counting or sampling of three-dimensional particles can be achieved by using the stereological method called disector principle (Sterio, 1984; Gundersen, 1986). The disector is a 3D probe which samples particles with a uniform probability in $3 \mathrm{D}$ space, irrespective of their size and shape, as shown in Fig 7.

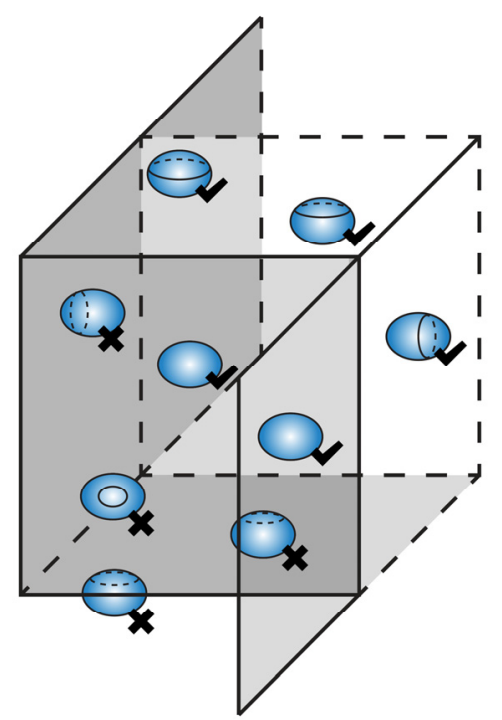

Fig. 7. Disector. Particles that are inside the $3 D$ disector probe are counted and particles intersecting its planes are also counted except those intersecting the exclusion planes (in grey). In this example, 5 particles are counted (ticked) and 4 particles are not counted (crossed). After Kubinová et al. (2014).

\section{PLANT ANATOMICAL CHARACTERISTICS ESTIMATED BY STEREOLOGICAL METHODS}

\section{Plant tissue volume density}

The volume density of a specific tissue in the leaf is usually estimated by the ratio of the area of the tissue section to the area of the leaf section. The corresponding areas were measured by a point-counting method, based on counting points of the test grid falling in the tissue under study (Chabot and Chabot, 1977; Pazourek, 1977; Pazourek and Nátr, 1981; Parkhurst, 1982; Hajibagheri et al., 1984; Gowland et al., 1987; Pazourek et al., 1987; Kubínová, 1991; Albrechtová, 1994), by a planimeter (Turrell, 1936), by cutting out the enlarged drawings of the sections and weighing them (El-Sharkawy and Hesketh, 1965; Charles-Edwards et al., 1972; Dengler and MacKay, 1975), by a semiautomatic image analyser (Parker and Ford, 1982) or by a stereological method based on length measurements (linear integration method, Weibel, 1979; Thain, 1983). A number of studies (e.g., Gundersen and Jensen, 1987) showed that, in general, the point-counting method using a regular grid of points (which is positioned uniformly at random on the section) is the most effective one. Its efficiency is low only if the structure is periodic with 
the same periodicity as the point grid. This can be avoided simply by changing the distances between the grid points.

The application of a point counting method for the estimation of the proportion of intercellular spaces in barley leaf was presented by Kubínová (1989b, 1991). Using this approach, the volume density of individual tissues in a leaf was measured by Edwards et al. (1999), Klich (2000), Luković et al. (2001), Bray and Reid (2002), Luković (2006), Marin et al. (2006), Zorić et al. (2011; 2014), Moura and Alves (2014), Bernardo et al. (2017), and Bertel et al. (2017). The proportion of intercellular spaces in mesophyll was also investigated by Albrechtová and Kubínová (1991), Kukkola et al. (2005), Albrechtová et al. (2007), Lhotáková et al. (2008), Yiotis and Psaras (2011), and Zorić et al. (2011; 2014). The proportion of intercellular spaces in the palisade parenchyma was measured by Konoplyova et al. (2008) from micrographs of paradermal sections of the leaves. Furthermore, volume density of needle tissues (Albrechtová et al., 2007; Lhotáková et al., 2012), trichomes in the leaf (Marin et al., 2008), and petiole tissues (Luković et al., 2016) were estimated.

The Cavalieri principle, which is based on multiplying the sum of areas of SURS sections by the distance between the subsequent sections (Gundersen and Jensen, 1987), was used for estimating volume of leaf and/or leaf components by Kubínová (1989b, 1991, 1993), Albrechtová and Kubínová (1991), Edwards et al. (1999), Klich (2000), Marin et al. (2008), and Albrechtová et al. (2007). Detailed instructions on how to apply this method are given in the overview of stereological methods for the measurement of leaf characteristics (Kubínová, 1993).

\section{Surface area of mesophyll cells and internal leaf surface area}

An unbiased stereological method of vertical sections (Baddeley et al., 1986) was applied for the estimation of internal leaf surface area (i.e., the surface area of mesophyll cell walls adjoining the intercellular spaces) and surface area of mesophyll cells (i.e., the surface area of entire mesophyll cell walls) by Kubínová (1991). The method is based on counting the intersections of a special cycloidal test system with the measured surface on 2D sections generated by using VURS (Fig. 6). For more details and practical application in both narrow and broad leaves see Kubínová (1993).

Another approach was presented by Kubínová and Janáček (1998) showing application of their fakir method for the estimation of the internal surface area of a barley leaf, and later by Albrechtová et al. (2007) and Lhotáková et al. (2008) for measuring the internal surface area of a conifer needle using confocal microscopy. Unlike the vertical sections method, which is applied to 2D physical sections, the fakir method does not require randomizing section orientation; hence the physical thick sections can be cut in any arbitrary direction. Therefore, the slices were cut perpendicular to the main axis of the needle, which is most suitable from a technical point of view (Fig. 6). The fakir method was used also by Lhotáková et al. (2012).

\section{Number of mesophyll cells and chloroplasts}

Unbiased counting or sampling of three-dimensional particles can be achieved by using the stereological method of disector (Sterio, 1984; Gundersen, 1986); for its principle see Fig. 7. Application of the disector method for estimation of mesophyll cell density and total number of mesophyll cells in a leaf was introduced by Kubínová (1989a,b; 1991). Detailed instructions on how to apply this method using SURS are given in her overview of stereological methods for estimating the number and sizes of stomata and mesophyll cells (Kubínová, 1994). The disector method for counting mesophyll cells was also used by Albrechtová and Kubínová (1991) and in combination with confocal microscopy by Kubínová and Janáček (2001), Kubínová et al. $(2002 ; 2005)$ and Albrechtová et al. (2007). Kubínová et al. (2014) also used confocal stereology introducing the application of the disector method for estimation of chloroplast number per mesophyll cell in Norway spruce needles and comparing this approach with other methods for chloroplast counting.

\section{Mean volume and surface area of mesophyll cells}

Mean volume and/or surface area of mesophyll cells is estimated simply by the ratio of the mesophyll cell volume, resp. surface area, and the mesophyll cell number (for the measurement of these characteristics see above). Unbiased stereological methods were used for estimation of these characteristics by Kubínová (1989a,b; 1991; 1994; 1998), Albrechtová and Kubínová (1991) and Albrechtová et al. (2007).

\section{PLANT CELL ULTRASTRUCTURE MEASUREMENTS}

Plant cell ultrastructure is often studied by transmission electron microscopy (TEM). Qualitative asses- 
sment of changes in chloroplasts (Fig. 8) or other cell components is common. Most studies focused on the accumulation of starch and/or plastoglobuli, formation of lipid bodies, fragmentation of vacuoles, condensation of cytoplasm, thylakoid swelling or electron density of stroma. In some studies, a system of classes is used to describe the severity of cellular injury (Wulff et al., 1996; Kivimäenpää et al., 2003).

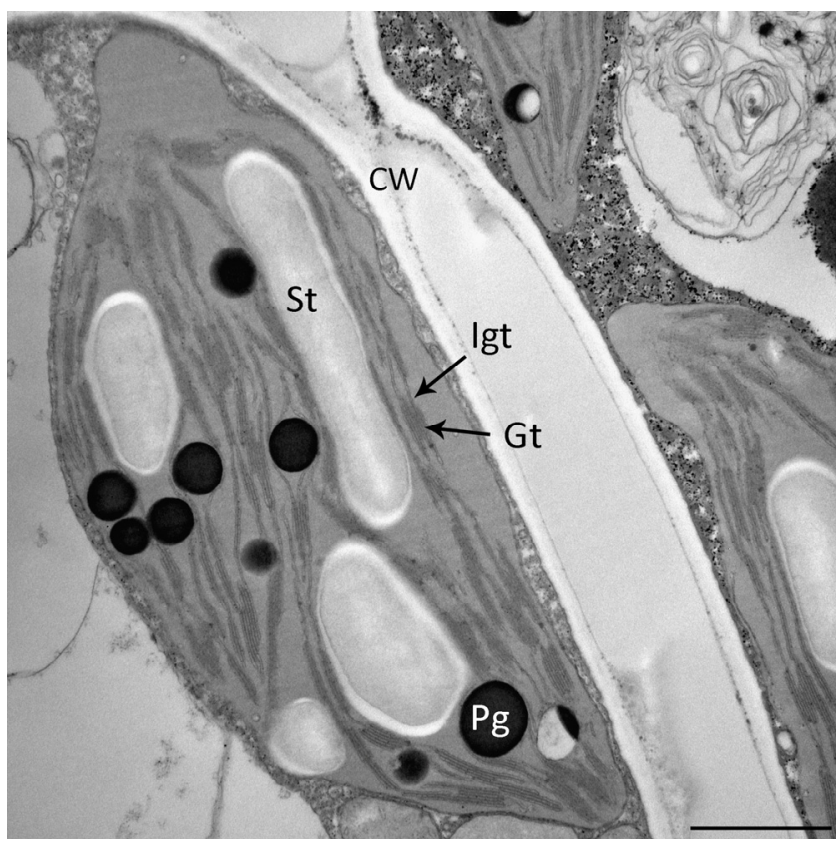

Fig. 8. Chloroplast ultrastructure. Transmission electron micrograph of chloroplast cross-section from leaf of European beech; Gt - granal thylakoids, Igtintergranal thylakoids, St - starch, Pg - plastoglobulus, $C W-$ cell wall. Bar $=1 \mu \mathrm{m}$.

It should be stated that although leaf ultrastructure was sometimes evaluated by stereological methods, the application of these methods was usually done without SURS at the leaf blade level. Due to the costs and time-consuming work associated with sample preparation for transmission electron microscopy, samples for analysis were taken from the middle part or the middle third of the leaf blade or needle (in the case of conifers). Random sampling within the leaf was sometimes applied but in many studies the description of sampling design was not given in detail. In conifers, samples were taken from the middle part of the needle cross-section or from the first layer of mesophyll. Furthermore, differences in ultrastructure between the outer and inner parts of mesophyll were evaluated, mainly in studies describing the effect of stress treatment (Kivimäenpää et al., 2003; Kivimäenpää et al., 2014). In bifacial leaves, the ultrastructure of palisade parenchyma cells is of greater interest than spongy parenchyma cells.
For stereological analysis, the volume density of a specific part of the cell (e.g., chloroplast, mitochondria, peroxisome) was estimated by the ratio of the area of the cell part to the area of the whole cell. Volume densities of thylakoids, starch, plastoglobuli and stroma inside chloroplasts were estimated by measuring the corresponding areas using the pointcounting method (Kutík et al., 1995; Miroslavov et al., 1996; Fagerberg and Bornman, 1997; Razem and Davis, 1999; Vassilyev, 2000; Wheeler and Fagerberg, 2000; Griffin et al., 2001; Gabarayeva and Grigorjeva, 2002; Pechová et al., 2003; Vičánková and Kutík, 2005; Gregoriou et al., 2007; Kubínová and Kutík, 2007; Holá et al., 2008, Mašková et al. 2017).

Volume densities were usually measured on randomly sampled images of cells or organelles. Their volumes were determined only in some of the studies: Fagerberg and Bornman (1997) and Wheeler and Fagerberg (2000) used the standard leaf volume for calculation of organelle volume; Vassilyev (2000) assumed ellipsoid form of different organelles (plastids, mitochondria, peroxisomes, and dictyosomes) and calculated their volumes from their lengths and widths.

For measurements of surface densities or surface area of chloroplasts, a Merz curvilinear grid with semi-circles in a square grid was used by Fagerberg and Bornman (1997). The method of „local vertical windows" suggested by Baddeley et al. (1986) was applied by Kubínová and Kutík (2007) for estimation of surface densities of thylakoid membranes. Albertsson and Andreasson (2004) estimated surface area of thylakoid membranes by drawing parallel lines across the chloroplast micrograph (perpendicular to the long axis of the chloroplast) and counting the number of membrane transections using the fact that the membrane length in randomly cut chloroplast sections is statistically proportional to the surface area of the membrane. A similar approach was also chosen by Gao et al. (2006).

\section{DISCUSSION}

\section{OTHER MORPHOMETRIC METHODS IN PLANT ANATOMY IN COMPARISON WITH STEREOLOGICAL METHODS}

In order to obtain a complex, full overview of the quantification of plant structures, it should be pointed out that many approaches other than stereological methods have been used in the past and are still being used today. However, compared to stereological methods, most methods as listed below provide biased results, most often due to improper sampling 
and model-based design application. Those methods regarding their relevance, precision, unbiasedness and efficiency will be discussed below.

\section{Plant tissue volume density}

Many authors did not measure the volume density of plant tissues in the entire leaf, but rather their tissue proportions in individual 2D sections located in nonrandomized specific positions of the leaf, e.g., only in the middle of the leaf (Soper and Mitchell, 1956; Sant, 1969; Charles-Edwards et al., 1972; 1974; Parker and Ford, 1982). Some used specialised image analysis software for this measurement (Niinemets, 2007; Lukjanova et al., 2013). However, this approach does not involve proper representative sampling, and thus it does not yield unbiased information about the proportion of tissues in the entire 3D organ.

The volume of intercellular spaces is often measured by the infiltration method (Unger, 1854; Nius, 1931; Czerski, 1968; Morrod, 1974; Byott, 1976; Smith and Heurer, 1981; Eleftheriou, 1987). Its drawbacks were discussed by Smith and Heurer (1981) and by Morris and Thain (1983). In short, the volume of intercellular spaces can be overestimated if the substance used for the infiltration enters the cells in addition to filling the intercellular spaces (Smith and Heurer, 1981), or it can be underestimated if tissue infiltration is incomplete (Morris and Thain, 1983). On the other hand, the estimation of the volume of intercellular spaces in the leaf by methods based on the evaluation of leaf section preparations can be affected by the microtechnical processing or by the section thickness effect.

\section{Surface area of mesophyll cells and internal leaf surface area}

Many different methods have been developed for the measurement of the internal leaf surface area (sometimes also called ,exposed surface area of mesophyll“). A particularly laborious procedure based on the evaluation of several transverse and paradermal sections of the leaf was proposed by Turrell (1936). The palisade and spongy mesophyll were treated separately and a kind of model shape of cells was assumed in both cases. The formula for the palisade mesophyll holds, for example, if the surface of all palisade cells exposed to the intercellular spaces are represented by the surface of cylinders (without their bases) having the same height and axes exactly perpendicular to the leaf surface. Any inclination, swelling or wrinkling of cell walls causes underestimation of the surface area of palisade cells. Similarly, the procedure described for the spongy parenchyma can lead to the underesti- mation or in some cases even to the overestimation of its surface area.

A less laborious, but similarly biased method was used by Dornhoff and Shibles (1976) for different tissue layers of a soybean leaf (Glycine max L.). The exposed surface area of different mesophyll layers was estimated by the product of the thickness of the tissue layer and the total length of the trace of exposed cell walls, obtained from paradermal sections. This procedure resulted in the underestimation of the exposed surface area, because it again assumes that the orientation of cell walls is exactly perpendicular to the leaf surface and that the walls are not curved.

This method for the measurement of the surface area of mesophyll cells, also used by Dengler and MacKay (1975) and later by other authors (Parker and Ford, 1982; Barbour and Farquhar, 2004), was criticized and modified by Thain (1983), who proposed several curvature correction factors eliminating the error caused by the curvature of cell surfaces, assuming different model shapes of mesophyll cells. Some of these mesophyll cell model shapes were more realistic than cylinders with hemispheres on each end (assumed by Nobel et al., 1975) or spheres (Bunce et al., 1977).

Thain's method (1983) was used also by Longstreth et al. (1985), Miyazawa and Terashima (2001) and Oguchi et al. (2003). Sasahara considered the palisade mesophyll cells of Brassiceae leaves as special solids of 'intermediate shapes between spheroids and columns' (Sasahara, 1971) and the mesophyll cells of Triticum as systems of interconnected cylinders with hemispheres on each end (Sasahara, 1982). A similar model of the Triticum mesophyll cell was used by Chonan (1965). It should be stressed here that it is always necessary to verify the appropriateness of the model for each type of structure under study, which may be difficult and laborious.

The stereological method, based on counting intersection points between the studied surface and line probes, has also been used for the estimation of the internal leaf surface area per unit leaf volume or the surface area of mesophyll cells per unit leaf volume. However, certain model assumptions were always considered. Morris and Thain (1983) claim that they achieved isotropic orientation of cell walls (i.e., with no preferred orientation) by preparing a suspension of the isolated mesophyll cells, which were then embedded and cut. The isotropic structure of the spongy mesophyll of tobacco (Nicotiana tabacum L.) leaf was assumed (and verified) by Gowland et al. (1987) who considered the palisade 
mesophyll as a partially orientated linear system of surfaces.

The stereological method based on counting intersections was also used by Parkhurst (1982) for the estimation of internal leaf surface area. Special models of mesophyll cells (cylindrical type, isotropic type, and a rather controversial intermediate type of structure) were assumed. Some of the pitfalls of Parkhurst's approach (disregarding the end surface of cylinder-like cells, subjective estimation of the degree of 'cylindricity' of the tissue) were discussed by Thain (1983). James et al. (1999) also used a model-based approach to the measurement of the mesophyll surface area per leaf area from oblique-paradermal sections - the latter exploited Image-Pro Plus software. Slaton and Smith (2002), Khramtsova et al. (2003), and Rhizoupoulou and Psaras (2003) also measured this parameter by model-based methods.

In summary, all the above mentioned methods for the estimation of surface area of mesophyll cells and internal leaf surface area were based on the choice of a specific, more or less realistic model of mesophyll cells. This model-based approach, when applied to real biological objects, such as mesophyll cells, brings about a bias which is challenging to quantify. Moreover, this approach cannot be reasonably used for the measurement of structures which cannot be approximated by simple geometrical models. This is the case for the mesophyll of grass leaves and coniferous needles where the cells have an irregularly lobed shape and possess a certain degree of anisotropy. Recently, Theroux-Rancourt et al. (2017) have tested several model-based methods for mesophyll surface area estimation. They found that the model-based methods often led to underestimation of this parameter (up to $30 \%$ ) in comparison with 3D method based on the evaluation of $3 \mathrm{D}$ image data acquired by microCT using specialized ImageJ plugins. However, they have not tested stereological methods, since "these methods have been less adopted in recent years".

Unbiased stereological methods can indeed avoid the above mentioned problems. They are using the design-based approach, where uniform random position and random orientation of line probes must be ensured, as is the case for the methods of vertical sections (Kubínová, 1993) and fakir method (Kubínová and Janáček, 1998) described above. This approach is precise and more efficient (especially the fakir method in combination with confocal microscopy as shown by Albrechtová et al., 2007) than model-based methods. Its advantages have been acknowledged by other authors (El-Sharkawy, 2009).

\section{Number of mesophyll cells and chloroplasts}

The number of mesophyll cells was usually determined by counting isolated cells after their maceration (Maksymowych, 1959; 1963; Smith, 1970; Morrod, 1974; Jellings and Leech, 1984; Sasahara, 1982; Lieckfeldt, 1989). This method may lead to the loss of cells during manipulation of the cell suspension or by damage to certain cells and, accordingly, to the underestimation of the cell number. Wilson and Cooper (1967) and Adachi et al. (2013) applied a 2D approach where they counted cell profiles while making assumptions about cell shapes, potentially leading to biased results. Using the stereological method of optical disector gives a theoretically unbiased result. However, in practice it is necessary to fulfil the so called General Requirement, i.e., each cell has to be unambiguously identifiable from its profiles in studied stacks of optical sections (i.e., 3D image data containing a disector probe, typically acquired by widefield or confocal microscope).

One of the most frequently used methods for the estimation of chloroplast number per mesophyll cell in herbaceous plants in 2D is counting chloroplasts in separated mesophyll cells obtained by maceration procedures as it was described by Possingham and Saurer (1969). This technique was used by many authors (Possingham and Smith, 1972; Boffey et al., 1979; Lamppa et al., 1980; Molin et al., 1982; Tymms et al., 1983; Sung and Chen, 1989; Pyke and Leech, 1991; Yamasaki et al., 1996; Marrison et al., 1999; Ivanova and P'yankov, 2002; Meyer et al., 2006; Stettler et al., 2009). This estimation is unbiased since counting is done in the whole cell, provided the chloroplasts in the specimen are not overlapping and the cells used for chloroplast counting are selected in an unbiased way. However, in some plant species it is impossible to macerate separate cells, especially in coniferous needles and leaves with mesophyll cells with lignified cell walls. In this case the disector method (Fig. 7) can be efficiently used for unbiased estimation of chloroplast number per mesophyll cell using confocal microscopy (Kubínová et al., 2014).

Practical and theoretical tests presented by Kubínová et al. (2014) demonstrated that the frequently used method for chloroplast number estimation by counting profiles of particles from 2D sections yielded biased estimates (e. g. Boffey et al., 1979; Miyazawa and Terashima, 2001; Sam et al., 2003; Zechmann et al., 2003; Wang et al., 2004; Hayashida et al., 2005; Oguchi et al., 2005; Teng et al., 2006; 
Gopi et al., 2008; Maslova et al., 2009; Jin et al., 2011; Simon et al., 2013) and that the results may be one order of magnitude different from the real chloroplast numbers. Another possible method is to count the chloroplasts in cells directly during focusing through the specimen using conventional light microscopy (Ellis and Leech, 1985; Bockers et al., 1997) which can be applied if entire cells can be focused through and the chloroplasts are sparsely distributed in cells. However, chloroplasts usually tend to be densely packed along the cytoplasmic membrane. The chloroplast number per cell was also determined in 3D reconstructions made from a series of confocal microscope images (Mozafari et al., 1997; Dinkins et al., 2001; Coate et al., 2012; Xu et al., 2012). Such a method can yield an unbiased estimate if SUR sampling is applied and a sufficient number of cells is analysed. However, this is a much more time-consuming approach than direct application of the disector method in combination with confocal microscopy. In conclusion, the disector method can be applied universally and provide unbiased estimation of the number of particles.

\section{Mean volume and surface area of mesophyll cells}

The volume of a mesophyll cell is usually estimated by the volume of a simple geometrical body by which the cell is approximated. Palisade cells were modelled by ellipsoids (Wild and Wolf, 1980) and cylinders (Maksymowych, 1963; Morrod, 1974; Gowland et al., 1987) or by cylinders with hemispherical ends (Sasahara, 1971; Barbour and Farquhar 2004; Burundukova et al., 2003; Khramtsova et al., 2003). Spongy cells were approximated by spheres (Morrod, 1974; Charles-Edwards et al., 1974) or ellipsoids (Wild and Wolf, 1980). Chonan (1965) and Sasahara (1982) modelled lobed mesophyll cells of wheat (Triticum sp.) by systems of parallel cylinders with hemispherical ends (standing side-by-side).

In most cases a model-based approach was chosen. Taking into account that it is often difficult to judge the appropriateness of the model used, this approach brings about a bias which is difficult to quantify. Moreover, this approach cannot reasonably be used for the measurement of cells which cannot be approximated by simple geometrical bodies.

As in the cell volume measurements, the modelbased approach to the measurement of the surface area of mesophyll cells prevailed (Chonan, 1965; Morrod, 1974; Sasahara, 1971; 1982; Bunce et al., 1977; Tichá and Čatský, 1977; Ivanova and P'yankov, 2002). It should be emphasized that, in comparison with the cell volume measurement, the estimation of the cell surface area by the surface area of a simple geometrical body can lead to even more pronounced bias since neither the inclinations, swellings nor wrinklings of the cell wall are taken into account. This can cause severe underestimation of the cell surface area.

In summary, unbiased stereological methods avoid the problems of model-based approach discussed above and can be recommended for mesophyll cell volume and surface area measurement. For this purpose, combination with confocal microscopy is especially useful (Albrechtová et al., 2007).

\section{OTHER METHODS FOR THE MEASUREMENT OF PLANT CELL ULTRASTRUCTURE}

Plant cell ultrastructure is recently most often quantified by image analysis on digitized images of plant cells or chloroplasts acquired by transmission electron microscopy (TEM). Typical parameters measured are thickness of the cell wall, size of organelles (length, width, profile area) - mostly of chloroplasts and mitochondria, proportions (in \%) and numbers of the organelles (Liu and Dengler, 1994; Lepeduš et al., 2001; Oksanen et al., 2001; Yu et al., 2017). Inside the chloroplasts, the size, number and profile area of starch grains, plastoglobuli and granal thylakoids are measured (Wulff et al., 1996; Pritchard et al., 1997; Schmitt et al., 1999; Bondada and Syvertsen, 2003; Riikonen et al., 2003). Thylakoids are also quite frequently counted and presented as numbers of thylakoids per granum (Demmig-Adams et al., 2015; Ren et al., 2017). It is a well-known fact that the number of thylakoids per granum is different for plants grown in sun or shade conditions (Boardman, 1977). Unfortunately, most studies do not describe sampling design in detail and counting of particles on 2D sections of chloroplasts or cells is probably biased in a similar way as in the case of chloroplast number estimation.

Some authors realize that counting particles in 2D may not be reliable. For example, Kivimäenpää et al. (2014) did not count the number of mitochondria on 2D sections, because they realized that the individual mitochondrial cross-sections can be from the same, long, branched and folded organelle.

3D methods for the determination of plant cell ultrastructure are used rather sparsely. In some studies (Perktold et al., 1998; Zellnig et al., 2004) the method of ultrathin serial sections was used as a way to build up a $3 \mathrm{D}$ image of the organelles, where the volumes of the organelles and their parts could be estimated 
(using Cavalieris principle). Crumpton-Taylor et al. (2012) used a FIB-SEM method for measurements of chloroplast and starch granule volume as well as granule numbers in Arabidopsis. In comparison with the serial sectioning and TEM, this method has advantages of speed and accuracy as there is no distortion of the image surface and alignment of the images is rather simple. Unfortunately, this method requires very expensive equipment. Using 3D methods, all starch granules inside the chloroplasts can be counted; any possible bias is thus limited to the possibility of incorrect sampling of small tissue samples or differential shrinkage of cell compartments during the sample preparations.

\section{SPARSE USE OF STEREOLOGY IN PLANT ANATOMY}

Although stereology provides a number of valuable tools for unbiased and precise measurement of plant structural characteristics, it has been used in this field sparsely until now. This is illustrated by the graph in Fig. 9 showing that the gap between the number of publications on stereology in plant science and their number in animal/human biosciences has been increasing since the 1990s. (The graph is just indicative as it is clear that it does not show all publications using stereological methods.)

What can be the reason for the sparse use of stereology in plant anatomy? It may be that many plant biologists are not acquainted with stereological methods and/or find them to be too complicated and laborious. In the community of plant biologists, broader publicity should be made through educational materials such as courses, tutorials, reviews, Wiki, etc. We envisage that this can be made possible on a broader scale by collaborative efforts such as the International Society for Stereology and Image Analysis (http://www.issia.net/). It should be made clear to the plant biological community that stereological methods are not so difficult to apply and yield unbiased results unlike many other methods, which can lead to erroneous results and, moreover, are often also quite tedious and time consuming. More studies bringing supporting arguments and comparisons of stereological and other methods should be made. This has been done, for example, for the estimation of volume and surface area of tobacco cell chains (Kubínová et al., 1999) where different stereological and image analysis methods were compared. In this case, it was concluded that the fakir method and the Cavalieri principle enable interactive, unbiased and efficient estimation of the cell surface area and volume.
It should also be noted that the application of automatic image analysis methods for measurements of plant structures is often limited by difficulties with proper automatic detection (segmentation) of these structures in microscopic images.

The popularity of stereological methods could also be increased by decreasing their laboriousness. This is possible by using specially dedicated software, either directly connected with image acquisition equipment, or stand-alone software modules. A combination with semi-automatic image analysis, while keeping proper sampling schemes, can also make measurements more efficient in some cases. Special attention should be paid also to the selection of suitable methods for each specific type of measurement and to the most efficient sampling design, as well as to all practical aspects of the measurement procedure.

Based on the above facts, we believe that stereology will find its way to the community of plant biologists and become one of the most powerful tools for investigation of plant anatomical and cytological structures.

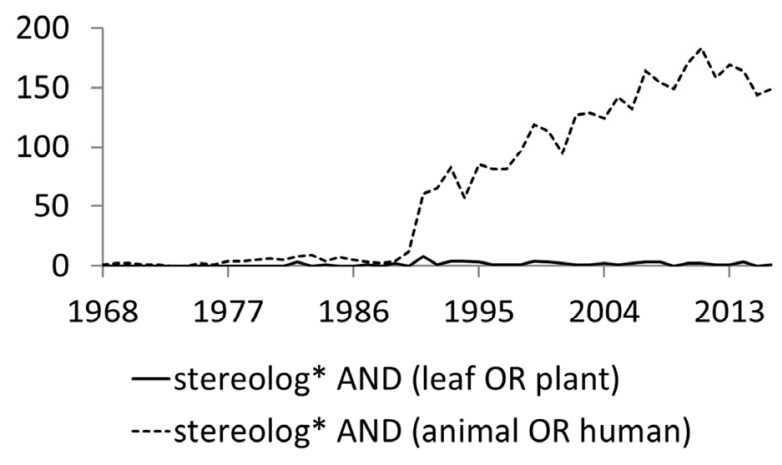

Fig. 9. Number of publications on stereology in plant and animal/human biosciences in the past 48 years, i.e., since the first publication including the key world stereolog* has appeared. Based on the result of search in Web of Science with key words (stereolog* AND (leaf OR plant)) or (stereolog* AND (animal OR human)), respectively.

\section{ACKNOWLEDGEMENTS}

This study was supported by the Ministry of Education, Youth and Sports of the Czech Republic (LM2015062 Czech-BioImaging project; NPUI LO1417 project; CZ.02.1.01/0.0/0.0/16_013/0001775 Modernization and support of research activities of the national infrastructure for biological and medical imaging Czech-BioImaging funded by $\mathrm{OP} \mathrm{RDE}$ ), project ERDF, OPPK BrainView CZ.2.16/3.1.00/21544, and by the project SVV of the Charles University. We 
thank Drahomíra Bartáková for technical help with anatomical preparations and Miroslav Barták (both from the Faculty of Science, Charles University) for his help with photographing and figure processing.

\section{REFERENCES}

Adachi S, Nakae T, Uchida M, Soda K, Takai T, Oi T, Yamamoto T, Ookawa T, Miyake H, Yano M (2013). The mesophyll anatomy enhancing $\mathrm{CO}_{2}$ diffusion is a key trait for improving rice photosynthesis. J Exp Bot 64:1061-72.

Albertsson P, Andreasson E (2004). The constant proportion of grana and stroma lamellae in plant chloroplasts. Physiol Plantarum 121:334-42.

Albrechtová J (1994). Quantitative analysis of leaves of sun and shade ecotypes of Solanum dulcamara L. Acta Stereol 13:467-72.

Albrechtová J, Janáček J, Lhotáková Z, Radochová B, Kubínová L (2007). Novel efficient methods for measuring mesophyll anatomical characteristics from fresh thick sections using stereology and confocal microscopy: application on acid rain-treated Norway spruce needles. J Exp Bot 58:1451-61.

Albrechtová J, Kubínová L (1991). Quantitative analysis of the structure of etiolated barley leaf using stereological methods. J Exp Bot 42:1311-14.

Albrechtová J, Kubínová L, Votrubová O, Eliášová K (1998). Non-destructive stereological method for estimating the length of rigid root systems. Biol Plantarum 40: 311-6.

Baddeley A, Gundersen H-JG, Cruz-Orive LM (1986). Estimation of surface area from vertical sections. J Microsc-Oxford 142:259-76.

Barbour M, Farquhar G (2004). Do pathways of water movement and leaf anatomical dimensions allow development of gradients in $\mathrm{H}_{2}{ }^{18} \mathrm{O}$ between veins and the sites of evaporation within leaves? Plant Cell Environ 27:107-21.

Bernardo S, Dinisa L-T, Luzio A, Pinto G, Meijón M, Valledor L, Conde A, Gerós H, Correia CM, MoutinhoPereira J (2017). Kaolin particle film application lowers oxidative damage and DNA methylation on grapevine (Vitis vinifera L.). Env Exp Bot 139:39-47.

Bertel C, Schönswetter P, Frajman B, Holzinger A, Neuner G (2017). Leaf anatomy of two reciprocally nonmonophyletic mountain plants (Heliosperma spp.): does heritable adaptation to divergent growing sites accompany the onset of speciation? Protoplasma 254:1411-20.

Boardman N (1977). Comparative photosynthesis of sun and shade plants. Ann Rev Plant Physio 28:355-77.

Bockers M, Čapková V, Tichá I, Schäfer C (1997). Growth at high $\mathrm{CO}_{2}$ affects the chloroplast number but not the photosynthetic efficiency of photoautotrophic Marchantia polymorpha culture cells. Plant Cell Tiss Org 48:103-10.
Boffey SA, Ellis JR, Selldén G, Leech RM (1979). Chloroplast division and DNA synthesis in lightgrown wheat leaves. Plant Physiol 64:502-5.

Bondada BR, Syvertsen JP (2003). Leaf chlorophyll, net gas exchange and chloroplast ultrastructure in citrus leaves of different nitrogen status. Tree Physiol 23:553-9.

Bray S, Reid DM (2002). The effect of salinity and $\mathrm{CO}_{2}$ enrichment on the growth and anatomy of the second trifoliate leaf of Phaseolus vulgaris. Can J Botany 80:349-59.

Buffon GLL (1777). Essai d'arithmétique morale. In: Histoire naturelle, générale et particulière: servant de suite à la théorie de la terre, \& d'introduction à l'histoire des minéraux. De l'imprimerie royale, Paris, pp 46-148.

Bunce JA, Patterson DT, Peet MM, Alberte RS (1977). Light acclimation during and after leaf expansion in soybean. Plant Physiol 60:255-8.

Burundukova O, Zhuravlev YN, Solopov N, P'yankov V (2003). A method for calculating the volume and surface area in rice mesophyll cells. Russian Journal of Plant Physiol 50:133-9.

Byott G (1976). Leaf air space systems in C3 and C4 species. New Phytol 76:295-9.

Chabot BF, Chabot JF (1977). Effects of light and temperature on leaf anatomy and photosynthesis in Fragaria vesca. Oecologia 26:363-77.

Charles-Edwards DA, Charles-Edwards J, Sant F (1972). Models for mesophyll cell arrangement in leaves of ryegrass (Lolium perenne L.). Planta 104:297-305.

Charles-Edwards DA, Charles-Edwards J, Sant F (1974). Leaf photosynthetic activity in six temperate grass varieties grown in contrasting light and temperature environments. J Exp Bot 25:715-24.

Chonan N (1965). Studies on the photosynthetic tissues in the leaves of cereal crops. I. The mesophyll structure of wheat leaves inserted at different levels of the shoot. Proc Crop Sci Soc Jpn 33:388-93.

Chonan N (1966). Studies on the photosynthetic tissues in the leaves of cereal crops. II. Effect of shading on the mesophyll structure of the wheat leaves. Proc Crop Sci Soc Jpn 35:78-82.

Chonan N (1970). Studies on the photosynthetic tissues in the leaves of cereal crops. V. Comparison of the mesophyll structure among seedling leaves of cereal crops. Proc Crop Sci Soc Jpn 39:418-25.

Coate JE, Luciano AK, Seralathan V, Minchew KJ, Owens TG, Doyle JJ (2012). Anatomical, biochemical, and photosynthetic responses to recent allopolyploidy in Glycine dolichocarpa (Fabaceae). Am J Bot 99:5567.

Crumpton-Taylor M, Grandison S, Png KM, Bushby AJ, Smith AM (2012). Control of starch granule numbers in Arabidopsis chloroplasts. Plant Physiol 158:905-16. 
Cruz-Orive LM, Howard CV (1991). Estimating the length of a bounded curve in three dimensions using total vertical projections. J Microsc-Oxford 163:101-13.

Czerski J (1968). Gasometric method of water deficit measurement in leaves. Biol Plantarum 10:275-83.

Demmig-Adams B, Muller O, Stewart JJ, Cohu CM, Adams WW (2015). Chloroplast thylakoid structure in evergreen leaves employing strong thermal energy dissipation. J Photoch Photobio B 152:357-66.

Dengler NG, MacKay LB (1975). The leaf anatomy of beech, Fagus grandifolia. Can J Botany 53:2202-11.

Dinkins R, Reddy SM, Leng M, Collins GB (2001). Overexpression of the Arabidopsis thaliana MinD1 gene alters chloroplast size and number in transgenic tobacco plants. Planta 214:180-8.

Dornhoff GM, Shibles R (1976). Leaf morphology and anatomy in relation to $\mathrm{CO}_{2}$-exchange rate of soybean leaves. Crop Sci 16:377-81.

Eames AJ, MacDaniels LH (1925). An Introduction to Plant Anatomy. McGraw-Hill Book Co. Inc., New York, pp. 321-42.

Edwards SJ, Isaac S, Collin HA, Clipson NJ (1999). Stereological analysis of celery leaves infected by Septoria apiicola. Mycol Res 103:750-6.

Eleftheriou E (1987). A comparative study of the leaf anatomy of olive trees growing in the city and the country. Environ Exp Bot 27:105-17.

Ellis J, Leech R (1985). Cell size and chloroplast size in relation to chloroplast replication in light-grown wheat leaves. Planta 165:120-5.

El-Sharkawy MA, Hesketh J (1965). Photosynthesis among species in relation to characteristics of leaf anatomy and $\mathrm{CO}_{2}$ diffusion resistances. Crop Sci 5: 517-21.

El-Sharkawy MA (2009). Pioneering research on $\mathrm{C}_{4}$ leaf anatomical, physiological, and agronomic characteristics of tropical monocot and dicot plant species: Implications for crop water relations and productivity in comparison to $\mathrm{C}_{3}$ cropping systems. Photosynthetica 47:163-83.

Fagerberg W (1983). A quantitative study of daily variation in the cellular ultrastructure of palisade chlorenchyma from sunflower leaves. Ann Bot-London 52:117-26.

Fagerberg WR, Bornman JF (1997). Ultraviolet-B radiation causes shade-type ultrastructural changes in Brassica napus. Physiol Plantarum 101:833-44.

Flood PJ, Kruijer W, Schnabel SK, van der Schoor R, Jalink H, Snel JFH, Harbinson J, Aarts MGM (2016). Phenomics for photosynthesis, growth and reflectance in Arabidopsis thaliana reveals circadian and longterm fluctuations in heritability. Plant Methods 12:14.

Gabarayeva NI, Grigorjeva VV (2002). Exine development in Stangeria eriopus (Stangeriaceae): ultrastructure and substructure, sporopollenin accumulation, the equivocal character of the aperture, and stereology of microspore organelles. Rev Palaeobot Palyno 122: 185-218.
Gamalei YuV, Kulikov GV (1978). Razvitie khlorenkhimy lista. [Development of leaf chlorenchyma.]. Nauka, Leningrad.

Gao H, Sage TL, Osteryoung KW (2006). FZL, an FZOlike protein in plants, is a determinant of thylakoid and chloroplast morphology. P Natl Acad Sci-Biol 103: 6759-64.

Gopi R, Jaleel CA, Panneerselvam R (2008). Leaf anatomical responses of Amorphophallus campanulatus to triazoles fungicides. Eurasia J Biosci 2, 46-52.

Gowland A, Briarty LG, Davey MR (1987). Tobacco leaf structure-an analytical problem. Acta Stereol 6:497-502.

Gregoriou K, Pontikis K, Vemmos S (2007). Effects of reduced irradiance on leaf morphology, photosynthetic capacity, and fruit yield in olive (Olea europaea L.). Photosynthetica 45:172-81.

Griffin KL, Anderson OR, Gastrich MD, Lewis JD, Lin G, Schuster W, Seemann JR, Tissue DT, Turnbull MH, Whitehead D (2001). Plant growth in elevated $\mathrm{CO}_{2}$ alters mitochondrial number and chloroplast fine structure. P Natl Acad Sci-Biol 98:2473-8.

Gundersen HJG, Jensen E (1987). The efficiency of systematic sampling in stereology and its prediction. $\mathrm{J}$ Microsc-Oxford 147:229-63.

Gundersen HJG (1986). Stereology of arbitrary particles a review of unbiased number and size estimators and the presentation of some new ones, in memory of Thompson, William, R. J Microsc-Oxford 143:3-45.

Hajibagheri M, Hall J, Flowers T (1984). Stereological analysis of leaf cells of the halophyte Suaeda maritima (L.) Dum. J Exp Bot 35:1547-57.

Hayashida A, Takechi K, Sugiyama M, Kubo M, Itoh R, Takio S, Fujita T, Hiwatashi Y, Hasebe M, Takano H (2005). Isolation of mutant lines with decreased numbers of chloroplasts per cell from a tagged mutant library of the moss Physcomitrella patens. Plant Biol 7:300-6.

Holá D, Kutík J, Kočová M, Rothová O (2008). Lowtemperature induced changes in the ultrastructure of maize mesophyll chloroplasts strongly depend on the chilling pattern/intensity and considerably differ among inbred and hybrid genotypes. Photosynthetica 46:32938.

Howard CV, Reed MG (1998). Unbiased stereology: threedimensional measurement in microscopy. Springer, New York.

Howard CV, Sandau K (1992) Measuring the surface area of a cell by the method of the spatial grid with a CSLM - a demonstration. J Microsc 165: 183-88.

Howard V, Reid S, Baddeley A, Boyde A (1985). Unbiased estimation of particle density in the tandem scanning reflected light microscope. J Microsc-Oxford 138:20312.

Ivanova L, P'yankov V (2002). Structural adaptation of the leaf mesophyll to shading. Russian Journal of Plant Physiol 49:419-31. 
James SA, Smith WK, Vogelmann TC (1999). Ontogenetic differences in mesophyll structure and chlorophyll distribution in Eucalyptus globulus ssp. globulus (Myrtaceae). Am J Bot 86:198-207.

Jellings AJ, Leech RM (1984). Anatomical variation in first leaves of nine Triticum genotypes, and its relationship to photosynthetic capacity. New Phytol 96:371-82.

Jin B, Wang L, Wang J, Jiang K-Z, Wang Y, Jiang X-X, Ni C-Y, Wang Y-L, Teng N-J (2011). The effect of experimental warming on leaf functional traits, leaf structure and leaf biochemistry in Arabidopsis thaliana. BMC Plant Biol 11:35.

Juurola E, Aalto T, Thum T, Vesala T, Hari P (2005). Temperature dependence of leaf-level $\mathrm{CO}_{2}$ fixation: revising biochemical coefficients through analysis of leaf three-dimensional structure. New Phytol 166: 20515 .

Khramtsova E, Kiseleva I, Lyubomudrova E, Malkova N (2003). Optimization of the leaf mesophyll structure in alloploid and diploid wheat species. Russian journal of Plant Physiol 50:19-27.

Kivimäenpää M, Sutinen S, Karlsson PE, Selldén G (2003). Cell structural changes in the needles of Norway spruce exposed to long-term ozone and drought. Ann BotLondon 92:779-93.

Kivimäenpää M, Riikonen J, Sutinen S, Holopainen T (2014). Cell structural changes in the mesophyll of Norway spruce needles by elevated ozone and elevated temperature in open-field exposure during cold acclimation. Tree Physiol 34:389-403.

Klich MG (2000). Leaf variations in Elaeagnus angustifolia related to environmental heterogeneity. Environ Exp Bot 44:171-83.

Konoplyova A, Petropoulou Y, Yiotis C, Psaras GK, Manetas $\mathrm{Y}$ (2008). The fine structure and photosynthetic cost of structural leaf variegation. Flora-Morphology, Distribution, Functional Ecology of Plants 203:653-62.

Kubínová L (1987). Application of stereological methods to the anatomy of the leaf blade of barley. Acta Stereol 6:99-104.

Kubínová L (1989a). Stereological analysis of the leaf of barley. Acta Stereol 8:19-26.

Kubínová L (1989b). Effect of light intensity on anatomical structure of the leaf blade of barley: Stereological analysis. Acta Stereol 8:389-94.

Kubínová L (1991). Stomata and mesophyll characteristics of barley leaf as affected by light: stereological analysis. J Exp Bot 42:995-1001.

Kubínová L (1993). Recent stereological methods for the measurement of leaf anatomical characteristics: estimation of volume density, volume and surface area. $\mathrm{J}$ Exp Bot 44:165-73.

Kubínová L (1994). Recent stereological methods for measuring leaf anatomical characteristics: estimation of the number and sizes of stomata and mesophyll cells. J Exp Bot 45:119-27.
Kubínová L (1998). Stereology in plant anatomy: application of recent stereological principles to evalution of plant cells. Fol Anat 26 (Suppl.1).:1-7.

Kubínová L, Janáček J (1998). Estimating surface area by the isotropic fakir method from thick slices cut in an arbitrary direction. J Microsc-Oxford 191:201-11.

Kubínová L, Janáček J (2001). Confocal microscopy and stereology: Estimating volume, number, surface area and length by virtual test probes applied to threedimensional images. Microsc Res Techniq 53:425-35.

Kubínová L, Janáček J (2015). Confocal stereology: an efficient tool for measurement of microscopic structures. Cell Tissue Res 360:13-28.

Kubínová L, Janáček J, Albrechtová J, Karen P (2005). Stereological and digital methods for estimating geometrical characteristics of biological structures using confocal microscopy. In: Evangelista V, Barsanti L, Passarelli V, Gualtieri P (eds). From Cells to Proteins: Imaging Nature across Dimensions. Springer, pp 271321.

Kubínová L, Janáček J, Guilak F, Opatrný Z (1999). Comparison of several digital and stereological methods for estimating surface area and volume of cells studied by confocal microscopy. Cytometry 36:85-95.

Kubínová L, Janáček J, Karen P, Radochová B, Difato F, Krekule I (2004). Confocal stereology and image analysis: methods for estimating geometrical characteristics of cells and tissues from three-dimensional confocal images. Physiol Res 53:S47-56.

Kubínová L, Janáček J, Krekule I (2002). Stereological methods for estimating geometrical parameters of microscopical structure studied by three-dimensional microscopical techniques. In: Diaspro A (ed). Confocal and Two-photon Microscopy. Wiley-Liss, New York, pp 299-332.

Kubínová L, Kutík J (2007). Surface density and volume density measurements of chloroplast thylakoids in maize (Zea mays L.) under chilling conditions. Photosynthetica 45:481-8.

Kubínová Z, Janáček J, Lhotáková Z, Kubínová L, Albrechtová J (2014). Unbiased estimation of chloroplast number in mesophyll cells: advantage of a genuine three-dimensional approach. J Exp Bot 65:609-20.

Kukkola E, Rautio P, Huttunen S (2005). Long-term symptoms due to metal and acid precipitation treatments in Scots pine (Pinus sylvestris). needles in the subarctic. Arct Antarct Alp Res 37:68-74.

Kutík J, Nátr L, Demmers-Derks H, Lawlor DW (1995). Chloroplast ultrastructure of sugar beet (Beta vulgaris L.) cultivated in normal and elevated $\mathrm{CO}_{2}$ concentrations with two contrasted nitrogen supplies. J Exp Bot 46:1797-802.

Kutík J, Šesták Z, Volfová A (1984) Ontogenetic changes in the internal limitations to bean-leaf photosynthesis. VIII: Primary leaf blade characteristics and chloroplast number, size and ultrastructure. Photosynthetica 18:1-8. 
Lamppa GK, Elliot LV, Bendich AJ (1980). Changes in chloroplast number during pea leaf development. Planta 148:437-43.

Lepeduš H, Cesar V, Ljubesic N (2001). Chloroplast ultrastructure and chlorophyll levels in vegetative buds and needles of Norway spruce (Picea abies L. Karst.). Period Biol 103(1): 61-5.

Lhotáková Z, Albrechtová J, Janáček J, Kubínová L (2008). Advantages and pitfalls of using free-hand sections of frozen needles for three-dimensional analysis of mesophyll by stereology and confocal microscopy. J Microsc-Oxford 232:56-63.

Lhotáková Z, Urban O, Dubánková M, Cvikrová M, Tomášková I, Kubínová L, Zvára $\mathrm{K}$, Marek MV, Albrechtová J (2012). The impact of long-term $\mathrm{CO}_{2}$ enrichment on sun and shade needles of Norway spruce (Picea abies): Photosynthetic performance, needle anatomy and phenolics accumulation. Plant Sci 188:60-70.

Lieckfeldt E (1989). Importance of leaf anatomy for characterization of primary leaf photosynthetic efficiency in different genotypes of wheat (Triticum). Photosynthetica 23:63-70.

Liu Y, Dengler NG (1994). Bundle sheath and mesophyll cell differentiation in the $\mathrm{C}_{4}$ dicotyledon Atriplex rosea: quantitative ultrastructure. Can J Botany 72:644-57.

Longstreth DJ, Bolaños JA, Goddard RH (1985). Photosynthetic rate and mesophyll surface area in expanding leaves of Alternanthera philoxeroides grown at two light levels. Am J Bot 72:14-9.

Lukjanova A, Mandre M, Saarman G (2013). Impact of alkalisation of the soil on the anatomy of Norway spruce (Picea abies) needles. Water Air Soil Poll 224:1620.

Luković J (2006). Stereological analysis of the flag leaf of some Triticum L. species. Cereal Res Commun 34: $1005-12$.

Luković J, Zorić L, Piperac J, Nagl N, Karanović D, Kekić SM, Milić D (2016). The analysis of petiole histological traits through an evaluation of water deficit tolerance of sugar beet genotypes. Sugar Tech 18:160-7.

Luković J, Kraljević-Balalić M, Vujičić D (2001). Characteristics of the flag leaf vascular tissue in two Triticum species. Cereal Res Commun 29: 151-8.

Maksymowych R (1959). Quantitative analysis of leaf development in Xanthium pensylvanicum. Am J Bot 46:635-44.

Maksymowych R (1963). Cell division and cell elongation in leaf development of Xanthium pensylvanicum. Am J Bot 50:891-901.

Marin M, Koko V, Duletić-Laušević S, Marin PD (2008). Micromorphology of trichomes of Thymus malyi (Lamiaceae). J Microsc-Oxford 232:406-9.

Marin M, Koko V, Duletić-Laušević S, Marin PD, Rančić D, Dajić-Stevanović Z (2006). Glandular trichomes on the leaves of Rosmarinus officinalis: Morphology, stereology and histochemistry. S Afr J Bot 72:378-82.
Marrison JL, Rutherford SM, Robertson EJ, Lister C, Dean C, Leech RM (1999). The distinctive roles of five different ARC genes in the chloroplast division process in Arabidopsis. Plant J 18:651-62.

Mašková $\mathrm{P}$, Radochová $\mathrm{B}$, Lhotáková Z, Michálek J, Lipavská H (2017). Nonstructural carbohydratebalance response to long-term elevated $\mathrm{CO}_{2}$ exposure in European beech and Norway spruce mixed cultures: biochemical and ultrastructural view. Can J Forest Res 47:1488-94.

Maslova T, Mamushina N, Sherstneva O, Bubolo L, Zubkova E (2009). Seasonal structural and functional changes in the photosynthetic apparatus of evergreen conifers. Russ J Plant Phys 56:607-15.

Meyer FJ (1923). Das trophische Parenchym. A. Assimilationsgewebe. In: Handbuch der Pflanzenanatomie. Allgemeiner Teil: Histologie (Linsbauer K, ed.), 2nd edn. Berlin, Bd. 5, 1. Hälfte: pp 1-87.

Meyer R, Yuan J, Afzal J, Iqbal M, Zhu M, Garvey G, Lightfoot DA (2006). Identification of Gsr1 in Arabidopsis thaliana: a locus inferred to regulate gene expression in response to exogenous glutamine. Euphytica 151:291-302.

Miroslavov EA, Voznesenskaya EV, Bubolo LS (1996). Chloroplast structure in northern plants in relation to chloroplast adaptation to arctic conditions. Russian Journal of Plant Physiol 43:325-30.

Miyazawa S, Terashima I (2001). Slow development of leaf photosynthesis in an evergreen broad-leaved tree, Castanopsis sieboldii: relationships between leaf anatomical characteristics and photosynthetic rate. Plant Cell Environ 24:279-91.

Molin WT, Meyers SP, Baer GR, Schrader LE (1982). Ploidy effects in isogenic populations of Alfalfa II. Photosynthesis, chloroplast number, ribulose-1,5bisphosphate carboxylase, chlorophyll, and DNA in protoplasts. Plant Physiol 70:1710-4.

Morris P, Thain J (1983). Improved methods for the measurement of total cell surface area in leaf mesophyll tissue. J Exp Bot 34:95-8.

Morrod R (1974). A new method for measuring the permeability of plant cell membranes using epidermisfree leaf discs. J Exp Bot 25:521-33.

Moura BB, Alves ES (2014) Climatic factors influence leaf structure and thereby affect the ozone sensitivity of Ipomoea nil 'Scarlet O'Hara.' Environ Pollut 194:11-6.

Mozafari J, Wolyn D, Ali-Khan S (1997). Chromosome doubling via tuber disc culture in dihaploid potato as determined by confocal microscopy. Plant Cell Rep 16:329-33.

Nátr L (1988). Quantitative anatomy of plants. Acta U Carol Biol 31:5-13.

Newman E (1966). A method of estimating the total length of root in a sample. J Appl Ecol 139-45.

Niinemets U (2007). Photosynthesis and resource distribution through plant canopies. Plant Cell Environ 30:1052-71. 
Nius E (1931). Untersuchungen über den Einfluß des Interzellularvolumens und der Öffnungsweite der Stomata auf die Luftwegigkeit der Laubblätter. $\mathrm{Jb}$ Wiss Bot 74:33-126.

Nobel PS, Zaragoza LJ, Smith WK (1975). Relation between mesophyll surface area, photosynthetic rate, and illumination level during development for leaves of Plectranthus parviflorus Henckel. Plant Physiol 55:1067-70.

Oguchi R, Hikosaka K, Hirose T (2003). Does the photosynthetic light-acclimation need change in leaf anatomy? Plant Cell Environ 26:505-12.

Oguchi R, Hikosaka K, Hirose T (2005). Leaf anatomy as a constraint for photosynthetic acclimation: differential responses in leaf anatomy to increasing growth irradiance among three deciduous trees. Plant Cell Environ 28: 916-27.

Oksanen E, Sober J, Karnosky D (2001). Impacts of elevated $\mathrm{CO}_{2}$ and/or $\mathrm{O}_{3}$ on leaf ultrastructure of aspen (Populus tremuloides). and birch (Betula papyrifera). in the Aspen FACE experiment. Environ Pollut 115: 437-46.

Paolillo Jr DJ, Falk RH (1966). The ultrastructure of grana in mesophyll plastids of Zea mays. Am J Bot 173-80.

Parker M, Ford M (1982). The structure of the mesophyll of flag leaves in three Triticum species. Ann BotLondon 49:165-76.

Parkhurst DF (1982). Stereological methods for measuring internal leaf structure variables. Am J Bot 69:31-9.

Pawley JB (1995). Handbook of biological confocal microscopy, 2nd edn. Plenum Press, New York.

Pawley JB (2006). Handbook of Biological Confocal Microscopy, 3rd edn. Springer US, Boston, MA.

Pazourek J (1966). Anatomical gradients. Acta U Carol Biol Suppl. 1/2:19-25.

Pazourek J (1969). Anatomical gradients of stomatal apparatus in leaves of Hordeum distichon L. Adv Front P1 Sci 23:9-18.

Pazourek J (1975). Transversale anatomische Gradienten in der Kartoffelknolle. Biol Plantarum 17:263-7.

Pazourek J (1977). The volumes of anatomical components in leaves of Typha angustifolia L. and Typha latifolia L. Biol Plantarum 19:129-35.

Pazourek J (1988). The evolution of quantitative plant anatomy. Acta Univ Carol, Biol 31:15-25.

Pazourek J, Nátr L (1981). Changes in the anatomical structure of the first two leaves of barley caused by the absence of nitrogen or phosphorus in the nutrient medium. Biol Plantarum 23:296-301.

Pazourek J, Nátr L, Marková L (1987). Genotype differences in the proportion of different tissues in the leaves of spring barley. Biol Plantarum 29:54-62.

Pechová R, Kutík J, Holá D, Kočová M, Haisel D, Vičánková A (2003). The ultrastructure of chloroplasts, content of photosynthetic pigments, and photochemical activity of maize (Zea mays L.) as influenced by different concentrations of the herbicide amitrole. Photosynthetica 41:127-36.

Perktold A, Zellnig G, Guttenberger H, Gailhofer M (1998). $3 \mathrm{D}$ reconstruction of chloroplasts and their ultrastructure using ultra-thin-serial-sections. Phyton-Horn- 38: 159-66.

Peterson DA (1999). Quantitative histology using confocal microscopy: implementation of unbiased stereology procedures. Methods 18:493-507.

Possingham JV, Saurer W (1969). Changes in chloroplast number per cell during leaf development in spinach. Planta 86:186-94.

Possingham JV, Smith JW (1972). Factors affecting chloroplast replication in spinach. J Exp Bot 23:1050-9.

Pritchard S, Peterson C, Prior S, Rogers H (1997). Elevated atmospheric $\mathrm{CO}_{2}$ differentially affects needle chloroplast ultrastructure and phloem anatomy in Pinus palustris: interactions with soil resource availa-bility. Plant Cell Environ 20:461-71.

Pyke KA, Leech RM (1991). Rapid image analysis screening procedure for identifying chloroplast number mutants in mesophyll cells of Arabidopsis thaliana (L.) Heynh. Plant Physiol 96:1193-5.

Razem FA, Davis AR (1999). Anatomical and ultrastructural changes of the floral nectary of Pisum sativum L. during flower development. Protoplasma 206:57-72.

Ren B, Liu W, Zhang J, Dong S, Liu P, Zhao B (2017). Effects of plant density on the photosynthetic and chloroplast characteristics of maize under high-yielding conditions. Sci. Nat. 104:12.

Rhizopoulou S, Psaras GK (2003). Development and structure of drought-tolerant leaves of the mediterranean shrub Capparis spinosa L. Ann Bot-London 92:37783.

Riikonen J, Oksanen E, Peltonen P, Holopainen T, Vapaavuori E (2003). Seasonal variation in physiological characteristics of two silver birch clones in the field. Can J Forest Res 33:2164-76.

Salisbury E (1928). On the causes and ecological significance of stomatal frequency, with special reference to the woodland flora. Philos T R Soc Lon B 216:1-65.

Sam O, Ramírez C, Coronado M, Testillano P, Risueño M del C (2003). Changes in tomato leaves induced by $\mathrm{NaCl}$ stress: leaf organization and cell ultrastructure. Biol Plantarum 47:361-6.

Sant F (1969). A comparison of the morphology and anatomy of seedling leaves of Lolium multiflorum Lam. and L. perenne L. Ann Bot-London 33:303-13.

Sasahara T (1971). Genetic Variations in Cell and Tissue Forms in Relation to Plant Growth.: II. Total Cell Surface Area in the Palisade Parenchyma and Total Cell Surface Area: Total Nitrogen Content Ratio in Relation to Photosynthetic Activity in Brassica. Jpn J Breed 21:61-8.

Sasahara T (1982). Influence of genome on leaf anatomy of Triticum and Aegilops. Ann Bot-London 50:491-7. 
Sawidis TH, Eleftheriou EP, Tsekos I (1989). The floral nectaries of Hibiscus rosa-sinensis in. A morphometric and ultrastructural approach. Nord J Bot 9:63-71.

Schmitt V, Kußmaul A, Wild A (1999). Interaction of elevated $\mathrm{CO}_{2}$ and ozone concentrations and irrigation regimes on leaf anatomy and carbohydrate status of young oak (Quercus petraea) trees. Z Naturforsch C 54:812-23.

Simon UK, Polanschütz LM, Koffler BE, Zechmann B (2013). High resolution imaging of temporal and spatial changes of subcellular ascorbate, glutathione and $\mathrm{H}_{2} \mathrm{O}_{2}$ distribution during Botrytis cinerea infection in Arabidopsis. PLoS One 8:e65811.

Slaton MR, Smith WK (2002). Mesophyll architecture and cell exposure to intercellular air space in alpine, desert, and forest species. Int J Plant Sci 163:937-48.

Slavík B (1963). The distribution pattern of transpiration rate, water saturation deficit, stomata number and size, photosynthetic and respiration rate in the area of the tobacco leaf blade. Biol Plantarum 5:143-53.

Smith H (1970). Changes in plastid ribosomal-RNA and enzymes during the growth of barley leaves in darkness. Phytochemistry 9:965-75.

Smith JAC, Heuer S (1981). Determination of the volume of intercellular spaces in leaves and some values for CAM plants. Ann Bot-London 48:915-7.

Soper K, Mitchell K (1956). The developmental anatomy of perennial ryegrass (Lolium perenne L.) New Zeal J Sci 37:484-504.

Steer MW (1981). Understanding cell structure. Cambridge University Press, Cambridge.

Sterio D (1984). The unbiased estimation of number and sizes of arbitrary particles using the disector. J Microsc-Oxford 134:127-36.

Stettler M, Eicke S, Mettler T, Messerli G, Hörtensteiner S, Zeeman SC (2009). Blocking the metabolism of starch breakdown products in Arabidopsis leaves triggers chloroplast degradation. Mol Plant 2:1233-46.

Sung F, Chen J (1989). Changes in photosynthesis and other chloroplast traits in lanceolate leaflet isoline of soybean. Plant Physiol 90:773-7.

Teng N, Wang J, Chen T, Wu X, Wang Y, Lin J (2006). Elevated $\mathrm{CO}_{2}$ induces physiological, biochemical and structural changes in leaves of Arabidopsis thaliana. New Phytol 172:92-103.

Thain J (1983). Curvature Correction Factors in the Measurement of Cell Surface Areas in Plant Tissues 1. J Exp Bot 34:87-94.

Théroux-Rancourt G, Earles JM, Gilbert ME, Zwieniecki MA, Boyce CK, McElrone AJ, Brodersen CR (2017). The bias of a two-dimensional view: comparing twodimensional and three-dimensional mesophyll surface area estimates using noninvasive imaging. New Phytol 215:1609-22.

Tichá I, Čatský J (1977). Ontogenetic changes in the internal limitations to bean leaf photosynthesis, 3: Leaf mesophyll structure and intracellular conductance for carbon dioxide transfer. Photosynthetica 11:361-6.

Turrell FM (1934). Leaf surface of a twenty-one-year old catalpa tree. Proc Iowa Acad Sci 41:79-84.

Turrell FM (1936). The area of the internal exposed surface of dicotyledon leaves. Am J Bot 23:255-64.

Tymms MJ, Scott NS, Possingham JV (1983). DNA content of Beta vulgaris chloroplasts during leaf cell expansion. Plant Physiol 71:785-8.

Unger F (1854). Beiträge zur Physiologie der Pflanzen. Sitzber d Wien Akad d Wiss 12:367.

Vassilyev AE (2000). Quantitative ultrastructural data of secretory duct epithelial cells in Rhus toxicodendron. Int J Plant Sci 161:615-30.

Vičánková A, Kutík J (2005). Chloroplast ultrastructural development in vascular bundle sheath cells of two different maize (Zea mays L.) genotypes. Plant Soil Environ 51:491-5.

Wang X, Anderson OR, Griffin KL (2004). Chloroplast numbers, mitochondrion numbers and carbon assimilation physiology of Nicotiana sylvestris as affected by $\mathrm{CO}_{2}$ concentration. Environ Exp Bot 51:21-31.

Wehrmeyer W, Röbbelen G (1965). Räumliche Aspekte zur Membranschichtung in den Chloroplasten einer Arabidopsis-Mutante unter Auswertung von Serienschnitten. Planta 64:312-29.

Weibel ER (1979). Stereological methods, Vol 1. Practical methods for biological morphometry. Academic Press, London.

Wheeler W, Fagerberg W (2000). Exposure to low levels of photosynthetically active radiation induces rapid increases in palisade cell chloroplast volume and thylakoid surface area in sunflower (Helianthus annuus L.) Protoplasma 212:38-45.

Wild A, Wolf G (1980). The effect of different light intensities on the frequency and size of stomata, the size of cells, the number, size and chlorophyll content of chloroplasts in the mesophyll and the guard cells during the ontogeny of primary leaves of Sinapis alba. Z Pflanzenphysiol 97:325-42.

Wilson D, Cooper J (1967). Assimilation of Lolium in relation to leaf mesophyll. Nature 214:989-92.

Wulff A, Ahonen J, Kärenlampi L (1996). Cell ultrastructural evidence of accelerated ageing of Norway spruce needles in industrial areas. New Phytol 133:553-61.

Wylie RB (1949). Differences in foliar organization among leaves from four stations in the crown of an isolated tree (Acer platanoides). Proc Iowa Acad Sci 56:18998.

Xu C-Y, Salih A, Ghannoum O, Tissue DT (2012). Leaf structural characteristics are less important than leaf chemical properties in determining the response of leaf mass per area and photosynthesis of Eucalyptus saligna to industrial-age changes in $\left[\mathrm{CO}_{2}\right]$ and temperature. $\mathrm{J}$ Exp Bot 63:5829-41. 
Yamasaki T, Kudoh T, Kamimura Y, Katoh S (1996). A vertical gradient of the chloroplast abundance among leaves of Chenopodium album. Plant Cell Physiol 37: 43-8.

Yiotis C, Psaras GK (2011). Dianthus caryophyllus stems and Zantedeschia aethiopica petioles/pedicels show anatomical features indicating efficient photosynthesis. Flora-Morphology, Distribution, Functional Ecology of Plants 206:360-4.

Yu W, Liu Y, Song L, Jacobs DF, Du X, Ying Y, Shao Q, $\mathrm{Wu} \mathrm{J}$ (2017). Effect of differential light quality on morphology, photosynthesis, and antioxidant enzyme activity in Camptotheca acuminata seedlings. J Plant Growth Regul 36:148-160.

Zechmann B, Müller M, Zellnig G (2003). Cytological modifications in zucchini yellow mosaic virus (ZYMV)infected Styrian pumpkin plants. Arch Virol 148:111933.

Zellnig G, Zechmann B, Perktold A (2004). Morphological and quantitative data of plastids and mitochondria within drought-stressed spinach leaves. Protoplasma 223:221-7.

Zorić L, Luković J, Matić-Kekić S, Merkulov L (2011). Modified stereological method for analysis of compound leaves and an example of its application. J Biol Syst 19:617-27.

Zorić L, Mikić A, Ćupina B, Luković J, Krstić D, Antanasović S (2014). Digestibility-related histological attributes of vegetative organs of barrel medic (Medicago truncatula Gaertn.) cultivars 3:257-64. 